\title{
Erratum to: Salinarubrum litoreum gen. nov., sp. nov.: a new member of the family Halobacteriaceae isolated from Chinese marine solar salterns
}

\author{
Heng-Lin Cui · Xing-Xing Qiu
}

Published online: 5 February 2014

(C) Springer International Publishing Switzerland 2014

\section{Erratum to: Antonie van Leeuwenhoek (2014) 105:135-141 \\ DOI 10.1007/s10482-013-0061-8}

Subsequent to the publication of the above paper it has been brought to our attention that the name proposed for the taxon represented by strains XD46 ${ }^{\mathrm{T}}$, YJ-63-S1 and ZS-1-H is not grammatically correct as "Salinarubrum" should have been proposed as Salinirubrum. We here propose the corrected name for the taxon represented by strain $\mathrm{XD} 46^{\mathrm{T}}$.

\section{Description of Salinirubrum gen. nov.}

Salinirubrum (Sa.li.ni.ru'brum. L. fem. pl. n. salinae salterns, salt works; L. neut. adj. rubrum red; M.L. neut. n. Salinirubrum the red archaeon from salt works).

The description of the genus is as given for Salinarubrum in Cui and Qiu (2014) Antonie van Leeuwenhoek 105:135-141.

The type species is Salinirubrum litoreum.

\section{Description of Salinirubrum litoreum}

Salinirubrum litoreum (li.to're.um. L. neut. adj. litoreum, of or belonging to the sea-shore).

The description of the species is as given for Salinarubrum litoreum in Cui and Qiu (2014) Antonie van Leeuwenhoek 105:135-141. The type strain is $\mathrm{XD}^{2} 6^{\mathrm{T}}\left(=\right.$ CGMCC $\left.1.12237^{\mathrm{T}}=\mathrm{JCM} 18649^{\mathrm{T}}\right)$.
The online version of the original article can be found under doi:10.1007/s10482-013-0061-8.

H.-L. Cui · X.-X. Qiu ( $₫)$

School of Food and Biological Engineering, Jiangsu University, 301 Xuefu Road, Jingkou District, Zhenjiang 212013, People's Republic of China

e-mail: cuihenglin@ujs.edu.cn 